\title{
Scientific substantiation and practical realization of selective comminution process of polymetallic mineral raw materials
}

\author{
Holger Lieberwirth ${ }^{1}$, Oleg Popov ${ }^{1}$, Tatiana Aleksandrova ${ }^{2 *}$, Nadezhda Nikolaeva ${ }^{2}$ \\ ${ }^{1}$ Technical University Bergakademie Freiberg, Freiberg, Germany \\ ${ }^{2}$ Federal State-Funded Educational Institution of Higher Professional Education "Saint Petersburg \\ Mining University", 199106, Saint Petersburg, Russia
}

\begin{abstract}
The results of various methods of studying structural and texture characteristics, physical and mechanical properties determining the liberation of ore minerals are presented in the article. They allow to estimate the content of ore minerals in them, to analyze particle size distribution and spatial distribution of their grains, etc. These data provide more detailed information on the strength properties of ore and the possibility of selective comminution at the stage of study and design of beneficiation schemes. The analysis of mineralogical and geochemical composition as well as the results of technological research have shown that investigated copper-nickel ores satisfy the criteria of selective comminution.
\end{abstract}

\section{Introduction}

At present, plant designers face a number of problems when developing new deposits. These problems, first of all, are connected with the quality of mineral raw materials: low quality, complex mineralogical and geochemical composition, complexity of mineralization, submicroscopic sizes of grains, exclusively heterogeneous textures and a variety of genetic processes of ore formation that causes additional expenses and complication of processing schemes of both, ore liberation and concentration already at the stage of designing a beneficiation plant [1-6]. For the purpose of optimization of the beneficiation plant project, technologists and engineers constantly try to find variants of rational organization of crushing and grinding processes within the limits of existing and new ore processing technologies, allowing to reduce losses in beneficiation processes due to a more complete liberation of grains.

Thus, the main target in ore beneficiation is the break-up of multi- mineral materials into components that can be used for industrial purposes with minimal costs, in particular for energy [7]. Taking into account the tendency to save natural resources and reduce the environmental impact, the search for energy-efficient disintegration and mineral processing technologies is an urgent scientific and technical task.

\footnotetext{
*Primary author: alexandrovat10@gmail.com
} 


\section{Objects and methods}

One way to solve this problem is to apply selective comminution and subsequent separation. This would allow not only to crush the rock mass to the required particle size, but also to carry out pre-concentration at the classification stage to obtain a preconcentrate and remove the waste rock into the tailings already at coarse stages. Selective comminution may leads to the selective formation and propagation of cracks in one or several components or along grain boundaries and, therefore, to differences in the distribution of the valuable component in the particle size fractions. The analysis of statistical and experimental data has shown that structural-texture features and physical-mechanical properties of rocks and ores have the main influence on the efficiency of comminution processes (especially the selective ones) in ore processing machines. The Pareto's diagram (Fig.1) was made on the basis of these results. This diagram shows the influence of different parameters on the shape of the particles in a comminution machine.

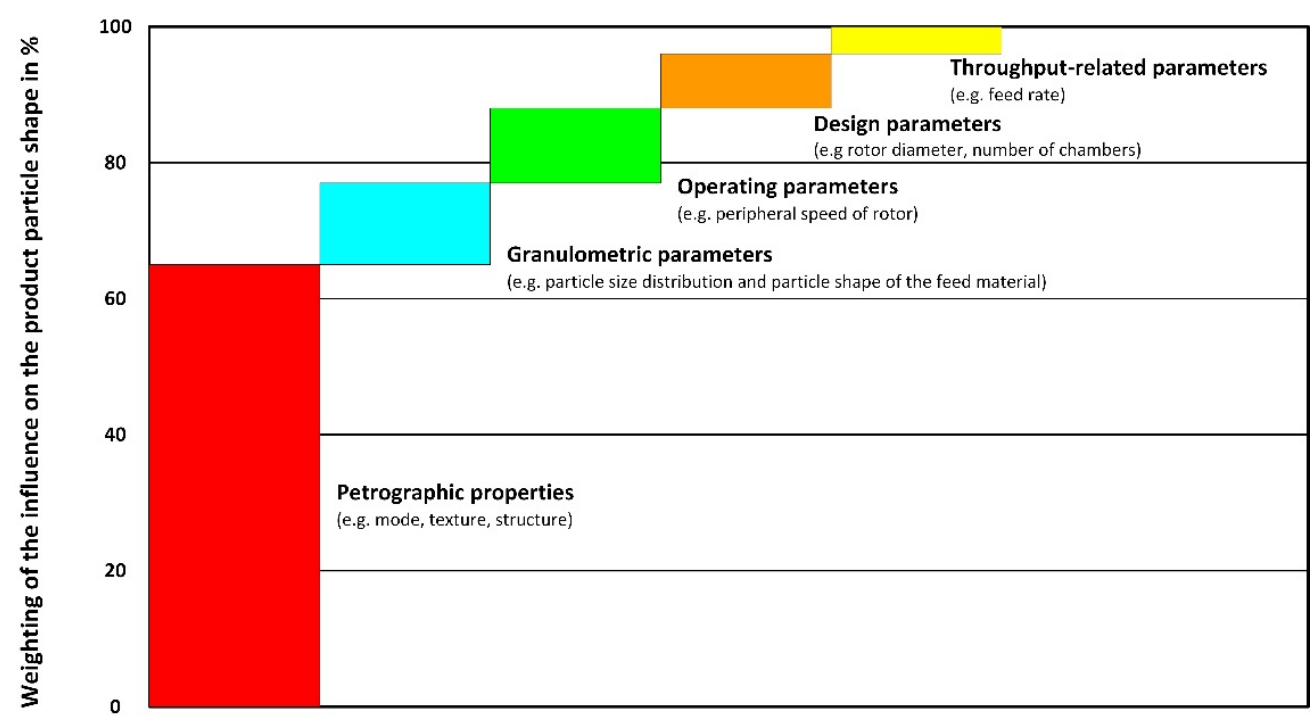

Main influencing factors

Fig.1. Pareto Diagram

Now the methods of technological mineralogy on the basis of mineralogical and petrographic analysis (quantitative analysis of microstructure (QMA), computer tomography, etc.) and tests for estimation of crushability and grindability of mineral raw materials are used for laying out effective schemes of ore beneficiation on the basis of definition and forecasting of strength characteristics of ore and degree of liberation [8-11]. But separately, each method has its advantages and disadvantages. Justification of the complex approach to the assessment of the possibility of selective comminution was the main purpose of this work, which under the current conditions is a very urgent task.

To use the effect of selective comminution in ore beneficiation processes, it is necessary to study in depth the properties of mineral components of an ore. A sample of copper-nickel ore from the Norilsk group of deposits was chosen as the object of study. A complex of researches, including investigation of internal structure and pore space using the method of computer tomography was carried out. The results of macro- and microscopic examination of ore samples as well as the results of XRF are presented in Fig. 2 and Table 1. 

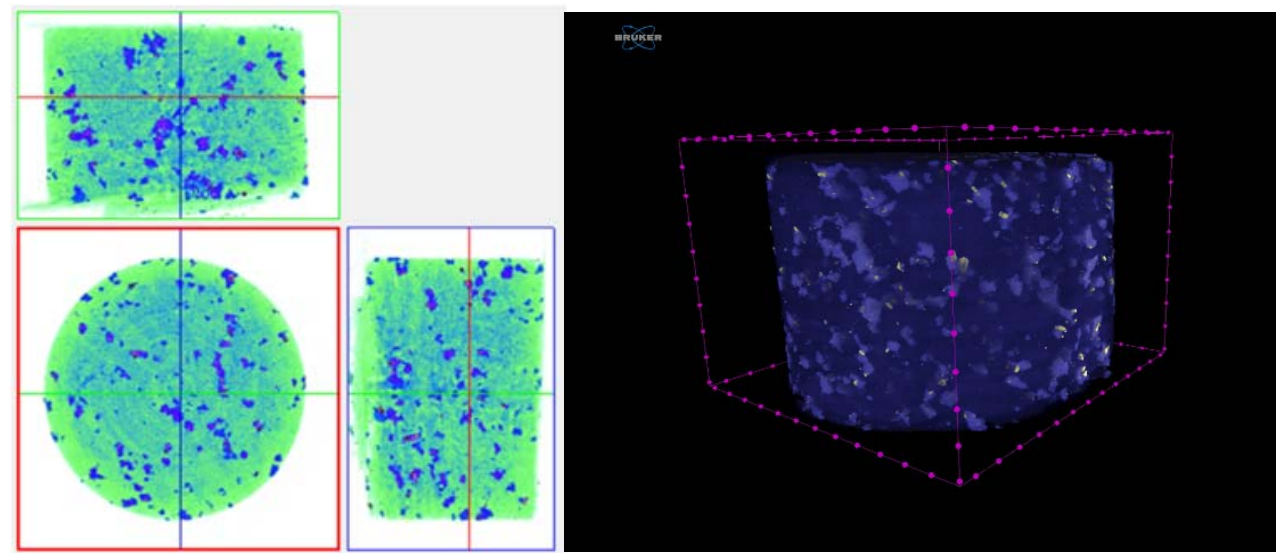

Fig. 2. Microscopic image of investigated samples of copper-nickel ore

Table 1. Chemical composition of the sample submitted

\begin{tabular}{|l|c|c|c|c|c|c|c|c|c|c|}
\hline \multicolumn{10}{|c|}{ Element } \\
\hline $\mathrm{SiO}_{2}$ & $\mathrm{Fe}_{2} \mathrm{O}_{3}$ & $\mathrm{CaO}$ & $\mathrm{SO}_{3}$ & $\mathrm{Al}_{2} \mathrm{O}_{3}$ & $\mathrm{~K}_{2} \mathrm{O}$ & $\mathrm{TiO}_{2}$ & $\mathrm{Cr}_{2} \mathrm{O}_{3}$ & $\mathrm{NiO}$ & $\mathrm{MnO}$ & $\mathrm{CuO}$ \\
\hline \multicolumn{8}{|c|}{ Content, \% } \\
\hline 37.619 & 29.924 & 12.478 & 8.496 & 6.456 & 0.924 & 1.349 & 1.042 & 0.856 & 0.341 & 0.515 \\
\hline
\end{tabular}

Analyzing the computer tomography results, ore minerals can be distinguished most effectively from the matrix minerals due to their substantially higher x-ray density. With the help of CTvox and CTan programs (Bruker, Belgium), not only the size of the grains that compose the rock, but also their relationships with each other were examined and analyzed in detail, which is especially important for the predictive evaluation of selective comminution. Porosity is one of the important features of rocks influencing strength and, respectively, comminution, since it connects the strength of the rock with the defect of its structure. It is therefore decisive in interpreting the strength properties and comminution behavior of the feed material. By results of researches it is possible to conclude that strength of rocks decreases with decrease in parameters of the open and closed porosity. It is also factor of the sphericity and density of pores.

\section{Results and discussion}

In the presented case, a database of laboratory test studies on crushability and grindability was collected for the analysis and detection of mathematical dependencies, comprising drop weight test, abrasivity index test, ultrasonic test, etc. (Table 2).

Table 2. Results of complex research of physical and mechanical properties

\begin{tabular}{|c|c|c|c|c|c|}
\hline $\begin{array}{c}\text { Series } \\
\text { Number }\end{array}$ & $\begin{array}{c}\text { Bond } \\
\text { Abrasivity } \\
\text { Index (AI), g }\end{array}$ & $\begin{array}{c}\text { Bond Impact } \\
\text { Crushing Index } \\
(\mathrm{BWI}),(\mathrm{kWh}) / \mathrm{t}\end{array}$ & $\begin{array}{c}\text { Parameter } \\
(\mathrm{ta})\end{array}$ & $\begin{array}{c}\text { Ultrasonic } \\
\text { Index (C) }\end{array}$ & $\begin{array}{c}\text { Young } \\
\text { Modulus } \\
(\mathrm{E}), \mathrm{GPa}\end{array}$ \\
\hline I & 0.0536 & 12.98 & 0.51 & 41.77 & 75.2 \\
\hline II & 0.0879 & 5.93 & 0.31 & 61.00 & 19.7 \\
\hline III & 0.1410 & 7.40 & 0.46 & 54.00 & 48.8 \\
\hline IV & 0.0965 & 6.21 & 0.39 & 58.00 & 38.9 \\
\hline
\end{tabular}

Figure 3 shows the dependencies ta $=\mathrm{f}(\mathrm{CWI})$ and $\mathrm{C}=\mathrm{f}(\mathrm{CWI})$ for 4 test series. 


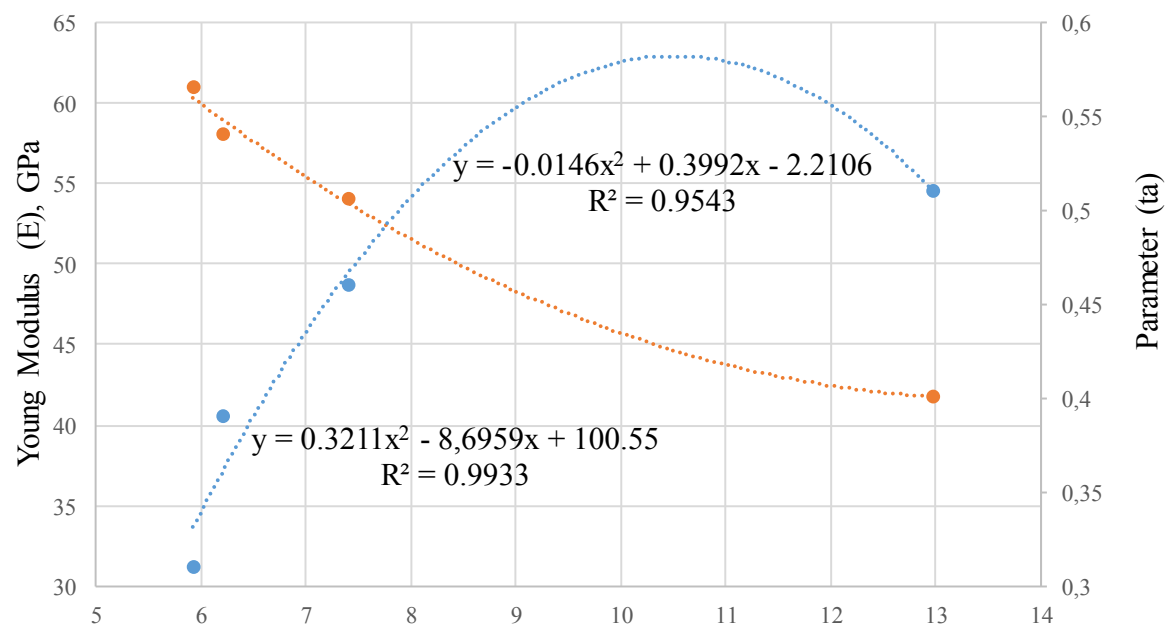

Bond Impact Crushing Index (BWI), (kWh)/t

Fig. 3. Statistical dependencies $t_{a}=f(T)$ and $C=f(C W I)$ for copper-nickel ore

Also for a comprehensive assessment of the possibility of selective comminution, a set of studies was carried out both at the grain boundaries and in the zone of grain to determine the microhardness of rock samples using the Micro-Hardness Tester Shimadzu HMV-G21 (Fig.4).
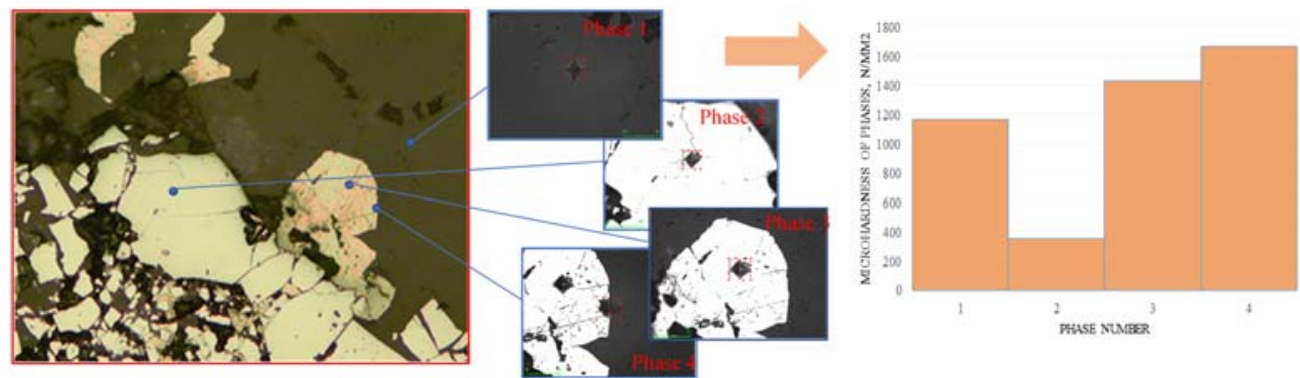

Fig. 4. Graphic visualization of micro-hardness tests for the copper-nickel ore sample

The conducted studies allowed to establish a connection between surface energy and microhardness of samples. At the same time the possibility of selective comminution application for this type of mineral raw materials was confirmed.

\section{Conclusion}

At present, selective comminution processes are used at beneficiation plants, but systematic studies of these processes are still lacking, as well as systematic data on the influence and interrelation of mineralogical-technological, structural-texture, and physicotechnical properties of minerals, rocks, and ores with the processes of selective comminution and flotation.

The carried out researches testify the wide possibilities of the considered complex of studying of mechanisms of comminution, development of liberation models, an estimation of content of ore minerals, the analysis of granulometric composition and spatial distribution 
of their grains, and so on. In turn, these data will allow at the stage of study and process layout to develop rational schemes of ore processing that will essentially reduce expenses for production of concentrates as a whole in respective plants.

The work was supported financially by the Russian Foundation of Fundamental Research (Project No. 20-55-12002/20).

\section{References}

1. V. A. Chanturiya, L. A. Vaysberg, \& A. P. Kozlov, Obogashchenie Rud, 2, 3-9 (2014).

2. T. N. Aleksandrova, I. V. Talovina, \& A. M. Duryagina, Gold-sulphide deposits of the russian arctic zone: Mineralogical features and prospects of ore benefication. Chemie Der Erde, doi:10.1016/j.chemer.2019.04.006 (2019)

3. M. Nevskaya, \& A. Cherepovitsyn, IOP Conference Series: Earth and Environmental Science, 302 (1) (2019)

4. M. N. Kruk, N. S. Guryleva, A. E. Cherepovitsyn \& A. Y. Nikulina, Non-Ferrous Metals, 44(1), 3-6 (2018)

5. T. N. Alexandrova, and C. O'Connor, Journal of Mining Institute, Available at: http://pmi.spmi.ru/index.php/pmi/article/view/13345 244 (2020)

6. A. O. Romashev, IOP Conference Series: Materials Science and Engineering, 665(1) (2019)

7. E. A. Hopunov Selective destruction of mineral and technogenic raw materials (in enrichment and metallurgy). - Yekaterinburg: "UIPC" LLC, 429 p. (2013)

8. V. Lvov, J. Sishchuk \& L. Chitalov, International Multidisciplinary Scientific GeoConference Surveying Geology and Mining Ecology Management, SGEM, 17(11) 857-864 (2017)

9. I.V. Talovina, T.N. Aleksandrova, O. Popov, H. Lieberwirth, Obogashchenie Rud. 3, 5662 (2017). DOI: 10.17580/or.2017.03.09

10. I.V. Talovina, H. Lieberwirth, T.N. Alexandrova, G. Heide, Eurasian Mining. 2017(1), 21-24 (2017). DOI: 10.17580/em.2017.01.06

11. T. Aleksandrova, N. Nikolaeva, H. Lieberwirth \& A. Aleksandrov, E3S Web of Conferences, 56 (2018). doi:10.1051/e3sconf/20185603001. 